\title{
Article \\ Phenolics of Aerial Parts of Gentiana lutea L. and Their Biological Activity
}

\author{
Erna Karalija ${ }^{1} \oplus$, Sanja Ćavar Zeljković ${ }^{2,3, *}$, Sabina Dahija ${ }^{1}$, Renata Bešta-Gajević ${ }^{4}$ and Adisa Parić ${ }^{1}$ \\ 1 Laboratory for Plant Physiology, Department of Biology, Faculty of Science, University of Sarajevo, Zmaja od \\ Bosne 33-35, 71000 Sarajevo, Bosnia and Herzegovina; erna.karalija@gmail.com (E.K.); \\ sabina_dudevic@yahoo.com (S.D.); adisacausevic@hotmail.com (A.P.) \\ 2 Centre of the Region Haná for Biotechnological and Agricultural Research, Department of Genetic Resources \\ for Vegetables, Medicinal and Special Plants, Crop Research Institute, Šlechtitelu 29, \\ 78371 Olomouc, Czech Republic \\ 3 Centre of Region Haná for Biotechnological and Agricultural Research, Czech Advanced Technology and \\ Research Institute, Palacky University, Šlechtitelu 27, 78371 Olomouc, Czech Republic \\ 4 Laboratory for Microbiology, Department of Biology, Faculty of Science, University of Sarajevo, Zmaja od \\ Bosne 33-35, 71000 Sarajevo, Bosnia and Herzegovina; renata_besta@yahoo.ca \\ * Correspondence: zeljkovic@vurv.cz or sanja.cavar@upol.cz
}

check for

updates

Citation: Karalija, E.; Ćavar Zeljković, S.; Dahija, S.; Bešta-Gajević, R.; Parić, A. Phenolics of Aerial Parts of Gentiana lutea L. and Their Biological Activity. Agronomy 2021, 11, 1442. https://doi.org/10.3390/ agronomy 11071442

Received: 2 July 2021

Accepted: 19 July 2021

Published: 20 July 2021

Publisher's Note: MDPI stays neutral with regard to jurisdictional claims in published maps and institutional affiliations.

Copyright: (c) 2021 by the authors Licensee MDPI, Basel, Switzerland. This article is an open access article distributed under the terms and conditions of the Creative Commons Attribution (CC BY) license (https:// creativecommons.org/licenses/by/ $4.0 /)$

\begin{abstract}
Gentiana lutea L. is a medicinal plant the roots of which are primarily used in treatments of various human digestive disorders, but also the production of alcoholic liquors. The roots (radix) of G. lutea are described in the European Pharmacopeia, but knowledge about the chemical composition and biological activities of its aerial parts is still limited. Thus, until today aerial parts of this species have not been used in medical treatments or consumed. Therefore, flowers, leaves, and stems extracts of G. lutea obtained by using four different extraction solvents (petrol ether, chloroform, ethanol, and water) were examined for their chemical composition and biological activities. High concentrations of salicylic acid, apigenin, and naringenin were recorded for ethanol stem extracts, while significant amounts of kaempferol were detected in leaves and flowers in chloroform and water extracts, respectively. The highest antioxidant potential was recorded for flower and stem petrol ether extracts with the lowest $\mathrm{IC}_{50}$ values, ranging from $94.46 \pm 9.45$ to $105.38 \pm 10.54 \mu \mathrm{g} / \mathrm{mL}$. Ethanol extracts of flowers and stems showed moderate antioxidant activity ( IC $_{50} 143.15 \pm 14.32$ and $146.90 \pm 14.69 \mu \mathrm{g} / \mathrm{mL})$ as well as strong antimicrobial activity against Candida albicans $(21.00 \pm 1.00$ and $27.50 \pm 1.78 \mathrm{~mm}$ inhibition zones, respectively). In addition, ethanol extracts had higher antimycotic activity compared to naturally occurring phenolic compounds that are used as positive controls. Moreover, statistical analysis of the activities of plant extracts and single compounds showed that levels of chlorogenic and caffeic acids strongly correlate with the biological activities of the extracts, i.e., they are the main carriers of these biological activities. The presented results indicate the possible use of aerial parts of G. lutea as a natural preservative, as well as a antimicrobial agent, which significantly amplifies the benefits of this medicinal crop and greatly affects the sustainability of cultivated Gentiana plantation.
\end{abstract}

Keywords: aerial parts; antimicrobial activity; antioxidant activity; chemical composition; Gentiana lutea $\mathrm{L}$.

\section{Introduction}

Members of the family Gentianaceae, which comprises more than 400 species, can be found from central and southern Europe, America, Australia, and New Zealand up to $2500 \mathrm{~m}$ of altitude. They are widely cultivated in China, continental and northern Europe, as well as in the Balkans [1]. Yellow gentian (Gentiana lutea) is an herbaceous perennial plant that grows in mountainous regions, on meadows and open slopes of the Eastern part of the Alps, and in the Balkan Peninsula [2,3]. 
The root of yellow gentian (Gentian root; Gentianae radix) is an official drug of European pharmacopeia [4], containing bitter active principles, and is primarily used in treatments of various human digestive disorders. Large amounts of the plant are consumed by the industry of alcoholic drinks for liquors and bitters [5]. It is noted that gentian extracts can stimulate neuritogenesis, without cytotoxic activity [6]. Petrol ether and alcohol extracts have been tested on rats as an oral medication for carrageenan-induced rat paw oedema, xylol-induced mouse ear oedema, and cotton pellet-induced chronic inflammatory models as inflammatory remedies [7]. The choleretic activity was recorded for ethanol root extracts, with significant hepatoprotective activity [8]. Active components of gentian root extracts are mainly secoiridoid bitter compounds. Root extracts exhibit remarkable antioxidant activity estimated by DPPH scavenging assay and Trolox equivalent antioxidant capacity [9]. Also, an inhibitory effect on the enzyme myeloperoxidase was recorded [10]. The antimicrobial activity of leaves and flowers was also recorded against Gram-positive and Gram-negative bacteria and yeast Candida albicans [11]. Extensive research of bioactive properties of Gentiana lutea extracts shows several additional effects such as anti-tubercular activity [12], radio-protective activity [13], CNS stimulation [14], anti-atherosclerotic effects [15], gastroprotective effects [16], and as ingredient in traditional remedies for atherosclerosis [15].

With the evidence for bioactive properties of gentian roots and some indications that above-ground parts can be used as a replacement for the radix in other Gentiana species [17], such as G. punctata and G. hederacea [18], this study aimed to evaluate the effect of the different solvents of extraction efficiency, adequate plant organ for extraction, and bioactive properties of obtained extracts.

\section{Materials and Methods}

\subsection{Collection of Samples and Extract Preparation}

Inflorescence samples of Gentiana lutea were collected at Mt. Bjelašnica in Bosnia and Herzegovina (Coordinates: $43.709376^{\circ}$ latitude; $18.578821^{\circ}$ longitude), during the flowering stage in August 2019. Specimens for Voucher were deposited under no. 374. Flowers, leaves, and stems were separated and air-dried for 7 days at room temperature $\left(23^{\circ} \mathrm{C}\right)$ in a shaded, well-ventilated room. Dried samples were powdered in the mill and stored at $+4{ }^{\circ} \mathrm{C}$ until use.

For each sample, $500 \mathrm{mg}$ of powdered plant material was soaked in $12.5 \mathrm{~mL}$ of solvent (petrol ether, chloroform, ethanol, and water) and sonicated for $30 \mathrm{~min}$ at $23{ }^{\circ} \mathrm{C}$. The supernatant was removed after centrifugation ( $5000 \mathrm{rpm}, 15 \mathrm{~min}$ ) and sediment was again soaked into the same solvent. Supernatants were combined for further analysis. Due to the high evaporation rate of petrol ether and chloroform, these extracts were evaporated to dryness and resuspended in dimethyl sulfoxide (DMSO).

\subsection{UHPLC-MS/MS Analysis}

UHPLC-MS/MS analysis of the extracts was performed on Nexera X2 UHPLC (Shimadzu Handels GmbH, Kyoto, Japan) coupled with an MS-8050 (Shimadzu Handels $\mathrm{GmbH}$, Kyoto, Japan). Chromatographic separation was performed on an UHPLC Acquity BEH C18 $(150 \times 3.0 \mathrm{~mm} ; 1.7 \mu \mathrm{m}$ particle size) column (Waters Corp., Milford, MA, USA) with the temperature set at $40{ }^{\circ} \mathrm{C}$. The mobile phase contained $10 \mathrm{mmol} / \mathrm{L}$ formic acid in water (A) and acetonitrile (B). All 32 target compounds were separated using a binary gradient starting at $5 \% \mathrm{~B}$ for $3 \mathrm{~min}$, increasing to $25 \% \mathrm{~B}$ for $4 \mathrm{~min}$, then increasing to $30 \%$ $\mathrm{B}$ for $6 \mathrm{~min}$, then increasing to $35 \% \mathrm{~B}$ for $4 \mathrm{~min}$, then increasing to $60 \% \mathrm{~B}$ for $6 \mathrm{~min}$, then increasing to $100 \% \mathrm{~B}$ for $4 \mathrm{~min}$, and isocratic run for $1.5 \mathrm{~min}$, and then back to $5 \% \mathrm{~B}$ for $0.1 \mathrm{~min}$, and equilibration for $3.4 \mathrm{~min}$. The flow rate was $0.4 \mathrm{~mL} / \mathrm{min}$ and the injection volume $10 \mu \mathrm{L}$.

All analytes were detected in negative ionization mode ESI. Multiple reaction monitoring (MRM) mode was used for their quantification. The spray voltage was $3 \mathrm{kV}$, and the vaporizer the ion transfer tube temperatures were $320^{\circ} \mathrm{C}$. 
Standard solutions of compounds (apigenin, 2,3-dihydroxybenzoic acid, caffeic acid, catechin, chlorogenic acid, chrysin, ferulic acid, galangin, gallic acid, hesperidin, 3hydroxybenzoic acid, 4-hydroxybenzoic acid, 5-hydroxyferulic acid, kaempferol, methyl pcoumarate, morin, myricetin, naringenin, naringin, $p$-coumaric acid, pinocembrin, quercetin, quercitrin, rosmarinic acid, rutin, salicylic acid, salicylic acid $2-\mathrm{O}-\beta$-D-glucoside, sinapic acid, syringic acid, trans-cinnamic acid, and vanillic acid), purchased from Sigma Aldrich Company, Germany, were firstly prepared in methanol at $1 \mathrm{mM}$ concentrations, and solutions were gradually diluted in the mobile phase to the working concentrations that ranged from 0.01 to $50 \mu \mathrm{M}$. Quantification was performed by the isotope diluting method using $p$-coumaric acid- $\mathrm{d}_{6}$ and salicylic acid- $\mathrm{d}_{4}$.

\subsection{GC/MS Analysis}

Volatile compounds were analyzed by GC/MS using a Hewlett-Packard GC/MS system (GC 7890 A; MSD 5975C series II, Palo Alto, CA, USA). For the GC conditions we used a fused silica HP-5MS UI column $(30 \mathrm{~m} \times 0.25 \mathrm{~mm} \times 0.25 \mu \mathrm{m})$, carrier gas He $(1.1 \mathrm{~mL} / \mathrm{min})$, with temperature program $3{ }^{\circ} \mathrm{C} / \mathrm{min}$ from $60{ }^{\circ} \mathrm{C}$ to $240{ }^{\circ} \mathrm{C}$; the temperature of the injection port was $250{ }^{\circ} \mathrm{C}$ and detector $280{ }^{\circ} \mathrm{C}$. Ionization was performed in the EI mode $(70 \mathrm{eV})$. The linear retention indices (RI) were determined by injection of the sample of $\mathrm{C}_{8}-\mathrm{C}_{26}$ n-alkanes. Compound identification was accomplished by comparing retention indices and mass spectra with literature data [19], by a computer library search (HP Chemstation computer library NBS75K.L, NIST/EPA/NIH Mass Spectral Library 2.0 and Mass Finder 4 Computer Software and Terpenoids Library), and in the laboratory's own database.

\subsection{DPPH (2.2-Diphenyl-1-picrylhydrazyl Radical) Assay}

DPPH (2.2-diphenyl-1-picrylhydrazyl radical) antioxidant capacity was evaluated for all four extracts and standards according to Meda et al. [20]. Antioxidant potential was evaluated according to the absorbance change of the free DPPH radical that is reduced by the potent antioxidant. Each extract (compound) was evaluated at 4 different concentration levels, and its antioxidant potential is presented as $\mathrm{IC}_{50}$ value (concentration of extract that scavenges $50 \%$ of DPPH radicals). Single phenolic compounds, i.e., morin, rosmarinic acid, chlorogenic acid, ferulic acid, coumaric acid, salicylic acid, 4-hydroxybenzoic acid, caffeic acid, quercetin, naringenin, and caffeic acid were used as positive controls.

\subsection{Antimicrobial Assay}

The agar well diffusion method was used to evaluate the antimicrobial activity of plant extracts and standards according to the National Committee for Clinical Laboratory Standards [21]. Each well contained $100 \mu \mathrm{L}$ of extract $(0.1 \mathrm{mg} / \mathrm{mL})$. Bacterial strains used in the analysis included Gram-positive: Enterococcus faecalis ATCC ${ }^{\circledR}$ 19433TM, Staphylococcus aureus subsp. aureus ATCC ${ }^{\circledR}$ 6538TM and Gram-negative bacteria: Salmonella abony NCTC ${ }^{\circledR}$ 6017TM, Escherichia coli ATCC ${ }^{\circledR}$ 8739TM, and the yeast Candida albicans ATCC ${ }^{\circledR} 10231$ TM. Bacterial strains were used as standardized inoculum of $5 \times 10^{5} \mathrm{CFU} / \mathrm{mL}$ using McFarland standard.

Müller-Hinton and Sabouard media were used for the cultivation of bacterial strains and yeast, respectively. Ampicillin was used as positive standards for bacterial strains and nystatin for Candida albicans. Ethanol and DMSO were used as negative controls. Antimicrobial activity of morin, rosmarinic acid, chlorogenic acid, ferulic acid, coumaric acid, salicylic acid, 4-hydroxybenzoic acid, caffeic acid, quercetin, naringenin, and caffeic acid in the concentration of $0.1 \mathrm{mg} / \mathrm{mL}$ was also evaluated. Antimicrobial effect was expressed as a diameter of inhibition zone in $\mathrm{mm}$ reduced by the inhibition zone of negative controls (solvents) if appropriate. 


\subsection{Statistical Analysis}

All data were analyzed using the STATISTICA 10.0 software (Statsoft Inc., Tulsa, OK, USA). Experimental results were presented in tables and graphs as the mean \pm standard deviation of three independent replications. Data obtained were subjected to variance analysis (ANOVA) and the Newman-Keuls post hoc test was carried out to identify significant differences between extract types. Mean values with $p<0.01$ were considered statistically significant. Pearson correlations were performed to observe the possible correlation between the phenolic profile, antioxidant capacity, and detected antimicrobial activity at the level of significance $p<0.01$.

\section{Results}

The phenolic composition of different extracts of flowers, leaves, and stems are reported in Table 1. A high concentration of phenolic acids was recorded in water extracts for flowers, with caffeic acid as the most abundant $(84.74 \pm 7.86 \mu \mathrm{mol} / \mathrm{g})$.

Significant amounts of this acid were also found in less polar extracts of flowers. Chlorogenic and 4-hydroxybenzoic acids were also found in significant amounts in all examined extracts. In general, flowers contain the highest amounts of these acids, while leaves contain the least.

Comparison of identified flavonoid components in different plant parts and different solvents showed a significant content of hesperidin in flower $(190.05 \pm 0.1 .36 \mu \mathrm{mol} / \mathrm{g})$, and naringenin in stem water extracts $(164.91 \pm 1.36 \mu \mathrm{mol} / \mathrm{g})$, (Table 1). Considerable amounts of naringenin were recorded for stems and leaves ethanolic extracts (102.61 \pm 0.72 and $91.00 \pm 6.99 \mu \mathrm{mol} / \mathrm{g}$, respectively), while high levels of apigenin were recorded for flowers $(166.5 \pm 1.19 \mu \mathrm{mol} / \mathrm{g})$ and stems $(158.13 \pm 20.79 \mu \mathrm{mol} / \mathrm{g})$ ethanol extract and in stems in chloroform extract $(114.90 \pm 3.61 \mu \mathrm{mol} / \mathrm{g})$.

GC/MS analysis of terpenoids indicated the presence of phytol in a higher percentage in leaves $(28.60 \%)$ and higher alkanes, $n$-heneicosane $(0.92-1.29 \%)$, n-docosane $(2.78-3.84 \%)$ n-tricosane (10.57-16.75\%), and in flowers and stems, respectively. Volatile terpenoids were not recorded in any of investigated plant extracts, which is in the agreement with the literature data $[6,22,23]$. However, these extracts were obtained from the roots of G. lutea, while the presented results apply for aerial parts.

The results of the antioxidant capacity of G. lutea extracts and single compounds found in the extracts are summarized in Tables 2 and 3. Total antioxidant capacity is expressed as $\mathrm{IC}_{50}$ value $(\mu \mathrm{g} / \mathrm{mL}$ concentration of the extract that inhibits $50 \%$ of DPPH radicals). Petrol ether flower and stem extracts showed the lowest $\mathrm{IC}_{50}$ values $(105.38 \pm 10.54 \mu \mathrm{g} / \mathrm{mL}$ and $94.46 \pm 9.45 \mu \mathrm{g} / \mathrm{mL}$, respectively) compared to other solvents used. The highest $\mathrm{IC}_{50}$ value was recorded for water leaves extract $(727.71 \pm 72.77 \mu \mathrm{g} / \mathrm{mL})$, which is in agreement with previously published data [24], where authors investigated the root extracts of yellow gentian.

Antioxidant activity of petrol ether extracts is strongly correlated to the presence of caffeic acid $(r=0.999)$, and hesperidin $(r=0.999)$, while for chloroform extracts correlation of antioxidant activity and presence of chlorogenic acid was recorded $(r=0.998)$, (Table 4).

The content of 4-hydroxybenzoic acid in ethanol extracts was highly correlated $(r=0.999)$ to the antioxidant capacity of these extracts. For water extracts antioxidant activity correlated to the content of chlorogenic $(r=0.996)$ and caffeic acid $(r=0.995)$. The antioxidant capacity of chlorogenic and caffeic acid, as well as hesperidin, was also evident (Table 4), which is in agreement with previously published results [24-26]. 
Table 1. Phenolic composition ( $\mu \mathrm{mol} / \mathrm{g}$ ) of extracts of aerial parts of Gentiana lutea.

\begin{tabular}{|c|c|c|c|c|c|c|c|c|c|c|c|c|}
\hline \multirow{2}{*}{ Compound } & \multicolumn{2}{|c|}{ Petrol Ether } & \multicolumn{4}{|c|}{ Chloroform } & \multicolumn{3}{|c|}{ Ethanol } & \multicolumn{3}{|c|}{ Water } \\
\hline & $\mathbf{F}$ & L & $\mathrm{S}$ & $\mathbf{F}$ & L & S & $\mathbf{F}$ & L & $\mathrm{S}$ & $F$ & $\mathbf{L}$ & $\mathrm{S}$ \\
\hline GA & nd & nd & nd & $0.16 \pm 0.00 *$ & nd & nd & nd & nd & nd & nd & nd & nd \\
\hline CGA & $1.26 \pm 0.02$ & $9.32 \pm 1.61$ & nd & $16.24^{\mathrm{c}} \pm 1.79$ & $12.32^{\mathrm{d}} \pm 0.04$ & $0.63^{\mathrm{f}} \pm 0.01$ & $21.62^{b} \pm 0.32$ & $18.99 \mathrm{bc} \pm$ & $15.64^{\mathrm{c}} \pm 1.48$ & $35.57^{\mathrm{a}} \pm 0.24$ & $7.00^{\mathrm{e}} \pm 0.91$ & $11.32^{\mathrm{d}} \pm 0.11$ \\
\hline CA & $3.67^{\mathrm{d}} \pm 0.02$ & nd & nd & $10.69^{\mathrm{d}} \pm 0.22$ & $6.18^{d} \pm 0.63$ & $18.81^{\mathrm{c}} \pm 2.48$ & $21.03^{b c} \pm 1.25$ & $8.95^{\mathrm{d}} \pm 0.16$ & $26.98^{b} \pm 3.83$ & $84.74^{\mathrm{a}} \pm 7.86$ & $14.89^{\mathrm{c}} \pm 0.42$ & $26.77^{b} \pm 1.41$ \\
\hline 3HBA & $4.35^{\mathrm{a}} \pm 0.42$ & nd & nd & $2.81^{b} \pm 0.07$ & nd & nd & $2.94^{b} \pm 0.17$ & nd & nd & nd & nd & nd \\
\hline$p C A$ & $13.30^{\mathrm{c}} \pm 0.77$ & $36.58^{\mathrm{a}} \pm 0.06$ & nd & $4.81 \mathrm{e} \pm 0.57$ & $11.39 \mathrm{~cd} \pm 1.19$ & $5.73^{e} \pm 0.98$ & $8.04^{\mathrm{d}} \pm 0.07$ & $9.42^{d} \pm 0.40$ & $20.78^{b} \pm 0.13$ & $14.35^{c} \pm 0.78$ & nd & $12.91^{\mathrm{c}} \pm 0.27$ \\
\hline FA & $18.48^{c} \pm 1.23$ & nd & nd & $23.83^{b c} \pm 1.53$ & $5.75^{\mathrm{e}} \pm 0.26$ & nd & $27.05^{\mathrm{ab}} \pm 4.27$ & $5.56^{\mathrm{e}} \pm 0.58$ & nd & $32.73^{\mathrm{a}} \pm 4.23$ & $4.60^{\mathrm{e}} \pm 0.33$ & $13.95^{\mathrm{d}} \pm 0.91$ \\
\hline RA & nd & nd & nd & nd & nd & nd & nd & nd & nd & $55.27^{\mathrm{a}} \pm 2.98$ & $35.34^{b} \pm 0.92$ & $36.28^{\mathrm{b}} \pm 0.29$ \\
\hline HSP & $2.77^{c} \pm 0.08$ & nd & nd & nd & nd & $1.41^{\mathrm{c}} \pm 0.04$ & nd & $18.79^{b} \pm 0.96$ & nd & $190.05^{\mathrm{a}} \pm 1.36$ & nd & nd \\
\hline RUT & $2.50^{\mathrm{a}} \pm 0.06$ & nd & nd & nd & nd & $1.88^{\mathrm{b}} \pm 0.15$ & nd & nd & nd & nd & nd & nd \\
\hline MOR & nd & nd & nd & nd & nd & $85.17 \pm 1.04$ & nd & nd & nd & nd & nd & nd \\
\hline APG & nd & nd & nd & $114.90^{b} \pm 3.61$ & nd & nd & $166.50^{\mathrm{a}} \pm 1.19$ & nd & $158.13^{a} \pm 20.79$ & $0.76^{\mathrm{d}} \pm 0.04$ & nd & $83.61^{\mathrm{c}} \pm 7.09$ \\
\hline NRG & nd & nd & nd & $13.84^{\mathrm{e}} \pm 0.58$ & nd & nd & $31.64^{\mathrm{d}} \pm 1.07$ & $91.00^{c} \pm 6.99$ & $102.61^{b} \pm 0.72$ & $1.80^{\mathrm{f}} \pm 0.06$ & $164.91^{\mathrm{a}} \pm 1.03$ & nd \\
\hline KMP & nd & nd & nd & nd & $156.56^{\mathrm{a}} \pm 3.13$ & nd & nd & nd & nd & $123.49^{b} \pm 5.80$ & nd & nd \\
\hline
\end{tabular}

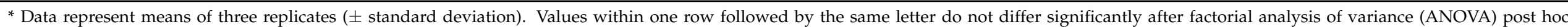

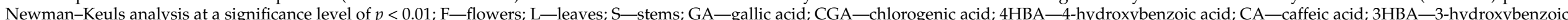

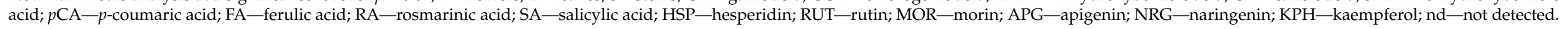


Table 2. Antioxidant and antimicrobial activities of extracts of aerial parts of Gentiana lutea.

\begin{tabular}{|c|c|c|c|c|c|c|c|}
\hline \multirow{2}{*}{ Solvent } & \multirow{2}{*}{ Plant Organ } & \multirow{2}{*}{$\begin{array}{l}\text { Antioxidant Activity } \\
\quad\left(\mathrm{IC}_{50} \mu \mathrm{g} / \mathrm{mL}\right)\end{array}$} & \multicolumn{5}{|c|}{ Antimicrobial Activity (Inhibition Zone mm) } \\
\hline & & & S. abony & E. coli & E. faecalis & S. aureus & C. albicans \\
\hline \multirow{3}{*}{ PE } & $\mathrm{F}$ & $105.38 \pm 10.54$ * & $12.00^{c} \pm 0.00$ & $13.67^{b c} \pm 1.15$ & $14.00^{\mathrm{d}} \pm 0.00$ & $12.33^{\mathrm{e}} \pm 0.58$ & $16.00^{g} \pm 0.00$ \\
\hline & $\mathrm{L}$ & $458.32 \pm 45.83$ & nd & nd & nd & $12.33^{\mathrm{e}} \pm 0.58$ & $17.67^{\mathrm{f}} \pm 1.53$ \\
\hline & S & $94.46 \pm 9.45$ & nd & $13.67^{b c} \pm 1.15$ & $13.00^{\text {ef }} \pm 0.00$ & $12.67^{\mathrm{e}} \pm 0.58$ & $17.33^{\mathrm{f}} \pm 0.58$ \\
\hline \multirow{3}{*}{$\mathrm{CH}$} & $\mathrm{F}$ & $454.56 \pm 45.46$ & $13.00^{\mathrm{bc}} \pm 1.00$ & $13.00^{\mathrm{bc}} \pm 1.00$ & $15.67^{\mathrm{d}} \pm 1.53$ & $16.33^{\mathrm{cd}} \pm 0.58$ & $21.67^{\mathrm{cd}} \pm 2.89$ \\
\hline & $\mathrm{L}$ & $506.14 \pm 50.61$ & $13.33^{b c} \pm 0.58$ & $12.33^{c} \pm 0.58$ & $13.33^{\mathrm{e}} \pm 1.53$ & $12.67^{\mathrm{e}} \pm 0.58$ & $19.33^{\mathrm{d}} \pm 1.15$ \\
\hline & S & $254.26 \pm 25.43$ & $12.00^{c} \pm 0.58$ & $13.67^{b c} \pm 0.00$ & $14.33^{\mathrm{e}} \pm 0.58$ & $13.00^{\mathrm{e}} \pm 1.29$ & $20.00^{\mathrm{d}} \pm 1.78$ \\
\hline \multirow{3}{*}{ ET } & $\mathrm{F}$ & $146.90 \pm 14.69$ & $14.00^{b} \pm 1.00$ & $15.67^{\mathrm{a}} \pm 1.15$ & $16.00^{\mathrm{d}} \pm 1.00$ & $17.00^{c} \pm 2.65$ & $21.00^{\mathrm{cd}} \pm 1.00$ \\
\hline & $\mathrm{L}$ & $455.40 \pm 45.54$ & $13.33^{b c} \pm 0.58$ & $14.00^{\mathrm{ab}} \pm 1.73$ & $15.67^{\mathrm{d}} \pm 0.58$ & $15.00^{\mathrm{d}} \pm 0.00$ & $29.33^{a} \pm 1.15$ \\
\hline & $S$ & $143.15 \pm 14.32$ & $13.67^{b c} \pm 0.58$ & nd & $15.33^{\mathrm{d}} \pm 0.58$ & $17.00^{c} \pm 1.29$ & $27.50^{b} \pm 1.78$ \\
\hline \multirow{3}{*}{ W } & $\mathrm{F}$ & $223.29 \pm 22.33$ & nd & nd & nd & nd & nd \\
\hline & $\mathrm{L}$ & $727.71 \pm 72.77$ & nd & nd & nd & nd & nd \\
\hline & $S$ & $257.08 \pm 25.71$ & nd & nd & nd & nd & nd \\
\hline
\end{tabular}

* Data represent means of three replicates ( \pm standard deviation). Values within one row followed by the same letter do not differ significantly after factorial ANOVA post hoc Newman-Keuls analysis at a significance level of $p<0.01$; PE-petrol ether; CH-chloroform; ET-ethanol; W-water; F-flowers; L-leaves; S-stems, nd-not detected.

Table 3. Antioxidant and antimicrobial activities of the phenolic constituents of G. lutea.

\begin{tabular}{|c|c|c|c|c|c|c|}
\hline \multirow{2}{*}{ Compound } & \multirow{2}{*}{$\begin{array}{l}\text { Antioxidant Activity } \\
\left.\quad \text { (IC }_{50} \mu \mathrm{g} / \mathrm{mL}\right)\end{array}$} & \multicolumn{5}{|c|}{ Antimicrobial Activity (Inhibition Zone mm) } \\
\hline & & S. abony & E. coli & E. faecalis & S. aureus & C. albicans \\
\hline 4-Hydroxybenzoic acid & $45.60 \pm 0.41 *$ & $12.33^{b c} \pm 1.53$ & $12.00^{c} \pm 0.00$ & $12.67^{\mathrm{f}} \pm 1.15$ & nd & $18.67^{\text {ef }} \pm 0.58$ \\
\hline Salicylic acid & $2.71 \pm 0.04$ & $13.50^{\mathrm{bc}} \pm 0.71$ & $13.00^{\mathrm{bc}} \pm 1.73$ & $13.00^{\text {ef }} \pm 1.73$ & nd & $25.33^{\mathrm{b}} \pm 0.58$ \\
\hline$p$-Coumaric acid & $17.76 \pm 1.78$ & $13.67^{\mathrm{bc}} \pm 0.58$ & $11.33^{c} \pm 0.58$ & $13.00^{\text {ef }} \pm 0.00$ & nd & $17.00^{\mathrm{f}} \pm 0.00$ \\
\hline Ferulic acid & $7.36 \pm 0.74$ & nd & $14.67^{\mathrm{ab}} \pm 0.58$ & nd & nd & nd \\
\hline Rosmarinic acid & $5.47 \pm 0.55$ & $13.00^{\mathrm{bc}} \pm 0.00$ & $13.33^{\mathrm{bc}} \pm 1.15$ & $12.67^{\mathrm{f}} \pm 1.15$ & $12.00^{\mathrm{e}} \pm 0.00$ & $17.33^{\mathrm{f}} \pm 1.15$ \\
\hline Chlorogenic acid & $5.62 \pm 0.56$ & $13.00^{b c} \pm 0.00$ & nd & nd & nd & $14.33^{\mathrm{h}} \pm 0.58$ \\
\hline Caffeic acid & $28.55 \pm 1.04$ & $14.33^{b} \pm 0.58$ & $11.33^{c} \pm 0.58$ & $18.0^{c} \pm 1.73$ & $12.00^{\mathrm{e}} \pm 1.00$ & $19.67^{\mathrm{d}} \pm 1.52$ \\
\hline Morin & $5.03 \pm 0.50$ & nd & nd & $15.67^{\mathrm{d}} \pm 1.53$ & $13.67^{\mathrm{e}} \pm 0.58$ & $18.00^{\text {ed }} \pm 1.73$ \\
\hline Naringenin & $7.04 \pm 0.18$ & nd & $12.33^{c} \pm 0.58$ & $23.00^{\mathrm{a}} \pm 1.00$ & $27.33^{b} \pm 2.31$ & $22.33^{c} \pm 1.52$ \\
\hline Ampicillin & - & $17.00^{\mathrm{a}} \pm 1.41$ & $14.00^{\mathrm{ab}} \pm 1.83$ & $19.50^{\mathrm{b}} \pm 0.71$ & $34.00^{\mathrm{a}} \pm 2.83$ & - \\
\hline Nystatin & - & - & - & - & - & $20.00^{\mathrm{cd}} \pm 1.41$ \\
\hline
\end{tabular}

${ }^{*}$ Data represent means of three replicates ( \pm standard deviation). Values within one row followed by the same letter do not differ significantly after factorial ANOVA post hoc Newman-Keuls analysis at a significance level of $p<0.01$.

Table 4. Correlations of the most abundant phenolic compounds and antibacterial and antioxidant activities of extracts of G. lutea.

\begin{tabular}{|c|c|c|c|c|c|c|c|}
\hline \multirow{2}{*}{ Compound } & \multirow{2}{*}{ Extract } & \multicolumn{5}{|c|}{ Antibacterial Activity } & \multirow{2}{*}{$\frac{\text { Antioxidant Activity }}{\text { DPPH }}$} \\
\hline & & S. abony & E. coli & E. faecalis & S. aureus & C. albicans & \\
\hline \multirow{5}{*}{ CGA } & PE & $0.992 *$ & 0.388 & 0.446 & -0.604 & -0.950 & -0.363 \\
\hline & $\mathrm{CH}$ & 0.999 & -0.961 & -0.161 & 0.195 & -0.001 & 0.998 \\
\hline & ET & -0.439 & 0.851 & 0.558 & -0.829 & 0.141 & 0.835 \\
\hline & W & $\mathrm{N} / \mathrm{A}$ & $\mathrm{N} / \mathrm{A}$ & $\mathrm{N} / \mathrm{A}$ & $\mathrm{N} / \mathrm{A}$ & $\mathrm{N} / \mathrm{A}$ & 0.996 \\
\hline & PE & 0.858 & -0.014 & 0.049 & -0.873 & -0.746 & 0.040 \\
\hline \multirow{3}{*}{$4 \mathrm{HBA}$} & $\mathrm{CH}$ & -0.386 & 0.115 & -0.848 & -0.980 & -0.922 & -0.429 \\
\hline & ET & -0.866 & 0.413 & 0.000 & -1.000 & 0.670 & 0.999 \\
\hline & $\mathrm{W}$ & $\mathrm{N} / \mathrm{A}$ & $\mathrm{N} / \mathrm{A}$ & $\mathrm{N} / \mathrm{A}$ & $\mathrm{N} / \mathrm{A}$ & $\mathrm{N} / \mathrm{A}$ & -0.997 \\
\hline \multirow{4}{*}{ CA } & PE & -0.500 & -1.000 & -0.997 & -0.500 & 0.654 & 0.999 \\
\hline & $\mathrm{CH}$ & 0.151 & 0.128 & 0.951 & 0.998 & 0.988 & 0.198 \\
\hline & $\mathrm{ET}$ & -0.657 & -0.813 & -0.981 & -0.192 & 0.857 & 0.182 \\
\hline & W & N/A & $\mathrm{N} / \mathrm{A}$ & $\mathrm{N} / \mathrm{A}$ & $\mathrm{N} / \mathrm{A}$ & $\mathrm{N} / \mathrm{A}$ & 0.995 \\
\hline \multirow{4}{*}{ SA } & PE & 0.687 & -0.285 & -0.223 & -0.972 & -0.537 & 0.310 \\
\hline & $\mathrm{CH}$ & 0.905 & -0.752 & 0.274 & 0.595 & 0.424 & 0.924 \\
\hline & ET & -0.569 & 0.763 & 0.427 & -0.904 & 0.288 & 0.908 \\
\hline & $\mathrm{W}$ & $\mathrm{N} / \mathrm{A}$ & N/A & $\mathrm{N} / \mathrm{A}$ & $\mathrm{N} / \mathrm{A}$ & $\mathrm{N} / \mathrm{A}$ & 0.676 \\
\hline \multirow{4}{*}{ HSP } & PE & -0.500 & -1.000 & -0.997 & -0.500 & 0.654 & 0.999 \\
\hline & $\mathrm{CH}$ & -0.970 & 0.866 & -0.082 & -0.427 & -0.240 & -0.981 \\
\hline & $\mathrm{ET}$ & 0.866 & 0.581 & 0.866 & 0.500 & -0.977 & -0.490 \\
\hline & $\mathrm{W}$ & $\mathrm{N} / \mathrm{A}$ & $\mathrm{N} / \mathrm{A}$ & $\mathrm{N} / \mathrm{A}$ & $\mathrm{N} / \mathrm{A}$ & $\mathrm{N} / \mathrm{A}$ & 0.998 \\
\hline
\end{tabular}

* Bolded correlations are significant at $p<0.05000, \mathrm{~N}=3$ (Casewise deletion of missing data); CGA-chlorogenic acid; 4HBA-4hydroxybenzoic acid; CA—caffeic acid; SA—salicylic acid; HSP-hesperidin; PE-petrol ether extract; CH-chloroform extract; ETethanol extract; W-aqueous extract, N/A-not analyzed. 
The results of the antimicrobial activity evaluation for G. lutea extracts are presented in Table 2. Leaves', flowers' and stems' petrol ether, chloroform and ethanol extracts inhibited the growth of all tested microorganisms depending on extract type. Most efficient were chloroform extracts exhibiting antimicrobial activity against all tested organisms; flower extracts having more prominent effects ranging from $13.00 \pm 0.00 \mathrm{~mm}$ inhibition zones against Salmonella abony to $21.67 \pm 2.89 \mathrm{~mm}$ for Candida albicans. All ethanol extracts showed a similar inhibitory effect against all tested microorganisms with higher efficiency against Candida albicans especially for leaves and stem extracts $(29.33 \pm 1.15$ and $27.50 \pm 1.78 \mathrm{~mm}$ inhibitory zone, respectively) compared to antimycotic nystatin (20.00 mm inhibitory zone). By contrast, water extracts showed no activity. The efficiency of the extract against bacteria is usually dependent upon the ability of the extract to act on the bacterial membrane by disrupting or increasing membrane permeability. It has been recorded that extracts containing acetone, ethanol, and methanol cause disruption and increase membrane permeability [27], while water alone cannot cause such damage to the bacterial membrane.

Positive correlations were recorded between the antimicrobial effect of chloroform extracts against Staphylococcus aureus and Salmonella abony and chlorogenic acid $(\mathrm{r}=0.999)$, (Table 4).

\section{Discussion}

Gentian roots are widely used in traditional medicine creating great demand and in parallel raising concerns about species' extinction. In Europe, different levels of concern are raised in the context of local use and exploitation levels [28]. For most European soils, data suggest an unfavorable or inadequate level of conservation and further steps need to be taken. For this study, collection of the samples was undertaken following guidelines on how to handle plants with unfavorable/endangered conservation status [29], therefore, population size was not impacted.

A high concentration of active compounds in flowers was previously recorded for methanol extracts [30], where the concentration of isogenistin was 10 times higher in flowers than in leaves. The high content of naringenin and hesperidin has been previously reported for Gentiana bitter liquors and by-products [31], where the concentration of naringenin and hesperidin were higher in by-products compared to the liquor. The biological activity of naringenin and hesperidin has been previously recorded as antioxidants and chemopreventive agents.

Within biological systems different primary reactive oxygen species (superoxide radical) and secondary ROS (hydroxyl radical, hydrogen peroxide, and singlet oxygen) are generated through enzyme or metal-catalyzed processes. For this reason, assessment of extract capacity for scavenging superoxide radicals is important. Differences between reducing the power of extracts can be attributed to solvent nature, quantitative and qualitative phytochemical profiles of different plant parts, plant age, method, and system used through the experiment $[10,24,32]$. The most effective were flower and stem extracts for petrol ether, ethanol, and water extracts with the same efficiency in radical scavenging, while for chloroform extracts stem extracts were most efficient with the lowest $\mathrm{IC}_{50}$ value. Higher efficiency of leaves' extracts in G. lutea compared to root extracts was previously reported [32], where $\mathrm{IC}_{50}$ value of $7.2 \mathrm{mg} / \mathrm{mL}$ for leaves and $19.0 \mathrm{mg} / \mathrm{mL}$ for root extracts were recorded compared to the present study. Lowest $\mathrm{IC}_{50}$ value was recorded for petrol ether flower extracts $(0.10 \mathrm{mg} / \mathrm{mL})$. Pure compounds had significantly lower values of $\mathrm{IC}_{50}$, compared to extracts, which is in agreement with the fact that synergism and concentration ratios of active compounds in plant extracts plays important roles in their biological activities [33].

The antimicrobial effect of this acid is probably the result of irreversible permeability changes in the cell membrane and due to the binding of the acid to DNA which results in inhibition of cellular functions. Salmonella abony is a Gram-negative bacteria, and the outer membrane of these bacteria consists of lipopolysaccharides (LPs) and proteins. Anionic substances can remove cations from the binding sites of LPs disrupting the membrane activ- 
ity. It was suggested that chlorogenic acid, due to its negative surface charge, binds to the outer membrane disrupting the membrane and leading to the loss of barrier function [30], which is related to data presented in this study. However, plant extracts may contain hundreds or even thousands of components, and identifying the compounds responsible for a given biological effect represents a significant challenge. Some studies have shown that the overall activity of plant extracts can result from mixtures of compounds with synergistic, additive, or antagonistic activity, and it is very common that when extracts are fractionated activity is lost [33,34].

Nevertheless, among individual naturally occurring components analyzed, the compound with the widest spectrum of activity was found to be rosmarinic acid, while the most potent compound was salicylic acid against $C$. albicans $(25.33 \pm 0.58 \mathrm{~mm}$ inhibitory zone). The efficiency of ethanol extracts against Candida albicans could be attributed to the presence of higher amounts of salicylic acid, apigenin, and naringenin as suggested by the results obtained for naturally occurring compounds and the presence of these compounds in extracts with high antimicrobial properties (Table 2). This fact is confirmed by correlating their levels and antimicrobial activities (Table 3). The antimicrobial effect of salicylic acid against bacteria and yeast is related to the enhancement of the effect of other extract compounds as well through salicylic acid's ability to prevent the adherence of bacteria and yeast to surfaces [35]. A combination of higher concentrations of salicylic acid and apigenin could be responsible for the high efficiency of the ethanol extracts against $C$. albicans, since apigenin can induce cell shrinkage in C. albicans [36].

\section{Conclusions}

Evaluation of the bioactive potential of aerial parts of Gentiana lutea suggested that ethanol extracts are the most diverse in chemical compounds with strong biological activity. Flowers' and stems' ethanol extracts showed moderate antioxidant activity with strong antimicrobial activity against Candida albicans. Ethanol extracts had higher antimycotic activity compared to isolated compounds. The highest antioxidant potential was recorded for flower and stem petrol ether extracts with the lowest $\mathrm{IC}_{50}$ values, while single compounds showed much lower $\mathrm{IC}_{50}$ values compared to all extracts. To conclude, in addition to Gentian radix, aerial parts of this medicinal plant could be used in the pharmaceutical and food industries, as they are rich sources of natural preservatives and antimicrobial agents. Our results indicate the possible use of aerial parts of G. lutea as a replacement for the roots, which in return would have a great effect on the sustainability of cultivated Gentiana plantation.

Author Contributions: Conceptualization, E.K. and S.Ć.Z.; methodology, S.Ć.Z. and E.K.; formal analysis, E.K., S.Ć.Z., S.D., R.B.-G. and A.P.; writing-original draft preparation, S.Ć.Z. and E.K.; writing-review and editing, S.Ć.Z. and E.K. All authors have read and agreed to the published version of the manuscript.

Funding: This work was funded by project No. RO0418 (Sustainable systems and technologies, improving crop production for a higher quality of production of food, feed, and raw materials, under conditions of changing climate) funded by the Ministry of Agriculture, Czechia and by the project "Plants as a tool for sustainable global development" (registration number: CZ.02.1.01/0.0/0.0/16_019/0000827) within the program Research, Development, and Education (OP RDE).

Institutional Review Board Statement: Not applicable.

Informed Consent Statement: Not applicable.

Data Availability Statement: The authors declare that the data supporting this study are available from the corresponding author on reasonable request.

Conflicts of Interest: The authors declare no conflict of interest. 


\section{References}

1. Alessandro, B.; Nicola, A. The cultivation of yellow gentian (Gentiana lutea L.) on the pre-Alps and Appenninic mountains: Results and applications (1). Acta Hortic. 1992, 331, 19-26. [CrossRef]

2. Tutin, T.G.; Heywood, V.H.; Burges, N.A.; Moore, D.A.; Valentine, D.H.; Walters, S.M.; Webb, D.A. Flora Europaea; University Press: Cambridge, UK, 1972; Volume 3, pp. 59-63.

3. Predić, T.; Pećanac, D.; Radanović, B.; Docić Kojadinović, T.; Radanović, D. Root and leaf mineral content of wild growing yellow gentian, Gentiana lutea L., from natural habitats in western part of Bosnia and Herzegovina. In Proceedings of the VII Conference on Medicinal and Aromatic Plants of Southeast European Countries, Subotica, Serbia, 27-31 May 2012; pp. 68-73.

4. European Pharmacopoeia, 10.5th ed.; Council of Europe: Strasbourg, France, 2021; p. 1448.

5. Marković, T.; Radanović, D.; Nastasijević, B.; Antić-Mladenović, S.; Vasić, V.; Matković, A. Yield, quality and safety of yellow gentian roots produced under dry-farming conditions in various single basal fertilization and planting density models. Ind. Crop. Prod. 2019, 132, 236-244. [CrossRef]

6. Mustafa, A.M.; Caprioli, G.; Maggi, F.; Vittori, S.; Sagratini, G. Comparative analysis of the volatile profiles from wild, cultivated, and commercial roots of Gentiana lutea L. by headspace solid phase microextraction (HS-SPME) coupled to gas chromatography mass spectrometry (GC-MS). Food Anal. Method 2015, 9, 311-321. [CrossRef]

7. Mathew, A.; Taranalli, A.D.; Torgal, S.S. Evaluation of anti-inflammatory and wound healing activity of Gentiana lutea rhizome extracts in animals. Pharm. Biol. 2004, 42, 8-12. [CrossRef]

8. Öztürk, N.; Herekman-Demir, T.; Öztürk, Y.; Bozan, B.; Başer, K.H.C. Choleretic activity of Gentiana lutea ssp. symphyandra in rats. Phytomedicine 1998, 5, 283-288. [CrossRef]

9. Azman, N.A.M.; Segovia, F.; Martínez-Farré, X.; Gil, E.; Almajano, M.P. Screening of antioxidant activity of Gentian lutea root and its application in oil-in-water emulsions. Antioxidants 2014, 3, 455-471. [CrossRef]

10. Nastasijević, B.; Lazarević-Pašti, T.; Dimitrijević-Branković, S.; Pašti, I.; Vujačić, A.; Joksić, G.; Vasić, V. Inhibition of myeloperoxidase and antioxidative activity of Gentiana lutea extracts. J. Pharm. Biomed. Anal. 2012, 66, 191-196. [CrossRef] [PubMed]

11. Šavikin, K.; Menković, N.; Zdunić, G.; Stević, T.; Janković, T. Antimicrobial activity of Gentiana lutea L. extracts and isolated compounds mangiferin, isogentisin and gentiopicrin. Planta Med. 2007, 73, P_151. [CrossRef]

12. Menkovic, N.; Savikin-Fodulovic, K.; Cebedzic, R. Investigation of the activity of Gentiana lutea extracts against Mycobacterium bovis. Pharm. Pharmacol. Lett. 1999, 9, 74-75.

13. Menkovic, N.; Juranic, Z.; Stanojkovic, T.; Raonic-Stevanovic, T.; Šavikin, K.; Zdunić, G.; Borojevic, N. Radioprotective activity of Gentiana lutea extract and mangiferin. Phytother. Res. 2010, 24, 1693-1696. [CrossRef] [PubMed]

14. Öztürk, N.; Başer, C.K.H.; Aydin, S.; Öztürk, Y.; Çaliş, I. Effects of Gentiana lutea ssp. symphyandra on the central nervous system in mice. Phytother. Res. 2002, 16, 627-631. [CrossRef]

15. Kesavan, R.; Potunuru, U.R.; Nastasijević, B.; Avaneesh, T.; Joksić, G.; Dixit, M. Inhibition of vascular smooth muscle cell proliferation by Gentiana lutea root extracts. PLoS ONE 2013, 8, e61393. [CrossRef] [PubMed]

16. Niiho, Y.; Yamazaki, T.; Nakajima, Y.; Yamamoto, T.; Ando, H.; Hirai, Y.; Toriizuka, K.; Ida, Y. Gastroprotective effects of bitter principles isolated from Gentian root and Swertia herb on experimentally-induced gastric lesions in rats. J. Nat. Med. 2006, 60, 82-88. [CrossRef]

17. Mirzaee, F.; Hosseini, A.; Jouybari, H.B.; Davoodi, A.; Azadbakht, M. Medicinal, biological and phytochemical properties of Gentiana species. J. Tradit. Complement. Med. 2017, 7, 400-408. [CrossRef] [PubMed]

18. Vogl, S.; Picker, P.; Mihaly-Bison, J.; Fakhrudin, N.; Atanasov, A.G.; Heiss, E.H.; Wawrosch, C.; Reznicek, G.; Dirsch, V.M.; Saukel, J.; et al. Ethnopharmacological in vitro studies on Austria's folk medicine-an unexplored lore in vitro anti-inflammatory activities of 71 Austrian traditional herbal drugs. J. Ethnopharmacol. 2013, 149, 750-771. [CrossRef]

19. Adams, R.P. Identification of Essential Oil Components by Gas Chromatography/Mass Spectrometry, 4th ed.; Allured Publ. Corp.: Carol Stream, IL, USA, 2007.

20. Meda, A.; Lamien, C.E.; Romito, M.; Millogo, J.; Nacoulma, O.G. Determination of the total phenolic, flavonoid and proline contents in Burkina Fasan honey, as well as their radical scavenging activity. Food Chem. 2005, 91, 571-577. [CrossRef]

21. NCCLS. Performance Standards for Antimicrobial Disc Susceptibility Tests; Approved Standard NCCLS Publication M2-A5: Villanova, PA, USA, 1993.

22. Arberas, I.; Leiton, M.J.; Domínguez, J.B.; Bueno, J.M.; Ariño, A.; de Diego, E.; Renobales, G.; de Renobales, M. The volatile flavor of fresh Gentiana lutea L. roots. Dev. Food Sci. 1995, 37, 207-234. [CrossRef]

23. Mustafa, A.M.; Caprioli, G.; Dikmen, M.; Kaya, E.; Maggi, F.; Sagratini, G.; Vittori, S.; Öztürk, Y. Evaluation of neuritogenic activity of cultivated, wild and commercial roots of Gentiana lutea L. J. Funct. Food 2015, 19, 164-173. [CrossRef]

24. Kintzios, S.; Papageorgiou, K.; Yiakoumettis, I.; Baricevic, D.; Kusar, A. Evaluation of the antioxidants activities of four Slovene medicinal plant species by traditional and novel biosensory assays. J. Pharm. Biomed. Anal. 2010, 53, 773-776. [CrossRef] [PubMed]

25. Genaro-Mattos, T.C.; Maurício, Â.Q.; Rettori, D.; Alonso, A.; Hermes-Lima, M. Antioxidant activity of caffeic acid against iron-induced free radical generation-a chemical approach. PLOS ONE 2015, 10, e0142402. [CrossRef]

26. Šilarová, P.; Boulekbache-Makhlouf, L.; Pellati, F.; Česlová, L. Monitoring of chlorogenic acid and antioxidant capacity of Solanum melongena L. (Eggplant) under different heat and storage treatments. Antioxidants 2019, 8, 234. [CrossRef] [PubMed] 
27. Crowley, L.C.; Scott, A.P.; Marfell, B.J.; Boughaba, J.A.; Chojnowski, G.; Waterhouse, N.J. Measuring Cell Death by Propidium Iodide Uptake and Flow Cytometry; Cold Spring Laboratory Press: Cold Spring Harbor, NY, USA, 2016; pp. 647-652.

28. European Topic Centre on Biological Diversity; European Environment Agency. Species: Gentiana lutea Report under the Article 17 of the Habitats Directive. 2012. Available online: https: / / eunis.eea.europa.eu/species/172882 (accessed on 30 June 2021).

29. UNDP Guidance Notes on the Social and Environmental Standards. Standard 1: Biodiversity Conservation and Sustainable Natural Resource Management. 2020. Available online: https://info.undp.org/sites/bpps/SES_Toolkit/SitePages/Standard\%20 1.aspx (accessed on 30 June 2021).

30. Šavikin, K.; Menković, N.; Zdunić, G.; Stević, T.; Radanović, D.; Janković, T. Antimicrobial activity of Gentiana lutea L. extracts. Z. Nat. C 2009, 64, 339-342. [CrossRef] [PubMed]

31. Mustafa, A.M.; Maggi, F.; Öztürk, N.; Öztürk, Y.; Sagratini, G.; Torregiani, E.; Vittori, S.; Caprioli, G. Chemical and biological analysis of the by-product obtained by processing Gentiana lutea L. and other herbs during production of bitter liqueurs. Ind. Crop. Prod. 2016, 80, 131-140. [CrossRef]

32. Kusar, A.; Zupancic, A.; Sentjurc, M.; Baricevic, D. Free radical scavenging activities of yellow gentian (Gentiana lutea L.) measured by electron spin resonance. Hum. Exp. Toxicol. 2006, 25, 599-604. [CrossRef]

33. Caesar, L.K.; Cech, N.B. Synergy and antagonism in natural product extracts: When $1+1$ does not equal 2. Nat. Prod. Rep. 2016, 36, 869-888. [CrossRef]

34. Lou, Z.; Wang, H.; Zhu, S.; Ma, C.; Wang, Z. Antibacterial activity and mechanism of action of chlorogenic acid. J. Food Sci. 2011, 76, 398-403. [CrossRef]

35. Farber, B.F.; Wolff, A.G. Salicylic acid prevents the adherence of bacteria and yeast to silastic catheters. J. Biomed. Mater. Res. 1993, 27, 599-602. [CrossRef] [PubMed]

36. Lee, H.; Woo, E.R.; Lee, D.G. Apigenin induces cell shrinkage in Candida albicans by membrane perturbation. FEMS Yeast Res. 2018, 18, foy003. [CrossRef] [PubMed] 